The modified cellulose and Whatman No. 1 filter paper show nearly oqual loss in weight when usod as substrates with living fungi, while with their enzyme solutions (eulture filtrates) the former substrate produces more sugar.

I thank the Research Director, Indian Jute Mills Association Research Institute, for permission to publish these results and also Dr. S. N. Basu for his interest.

R. G. Bose

Microbiology Section,

Indian Juto Mills Association Research Institute, Calcutta 27.

${ }^{1}$ Hungate, 1R. L,, Ract. Rev., 14, 1 (1950).

${ }^{2}$ Hazra, A. K., Bose, S, K, and (tuha, B. C, Soi. and Culture, 24, 39 (1958).

$\checkmark$ Eggins, H. O. W., and Pugh, G. J. F., Nature, 193, 94 (1962).

"Chakravarty, T., Bose, R. G., and Basu, S. N., App. Mierobiol. (in the press).

"Fuller, W. H., and Norman, A. G., Proe. Soil Sci. Soe. Amer., "y, 243 (1942).

"Wareup, J., Nature, 166, 117 (1950).

\section{Build-up and Decline of Ammonia and Acidity in Grass after Successive Sowings and Regrowth}

THe concomitant build-up and decline of ammonia and acidity during the early growth stage of the grass Setaria sphacelata has alroudy been roportod ${ }^{1}$. This behaviour did not occur with another grass Brachiaria ruziziensis grown under identical field conditions and similar in chemical constitution. The noxt step was to determino whethor this behaviour would reoceur after a second sowing of the grasses in 1962 and also during regrowth following application of ammonium sulphate (2 ewt/aore) aftor the mature grasses grown in 1961 had been cut back. This would show whether the behaviour with Setaria was due to abnormal soil or climatic conditions or to an inherent property of the grass.

There was no ovidence with Brachiaria of any build-up and decline of wator-soluble ammonia and acidity after the $196 \mathrm{~L}$ and 1962 sowings or during regrowth after the mature material sown in 1961 was eut baek in 1962 . With Setaria it occurred in all three instancos, as shown in Table I.

Table 1. MG/100g (PEAK Values)

$\begin{array}{ccc}\mathrm{NH}_{4}-\mathrm{N} & \mathrm{H} \text { (titratable) } & p \mathrm{H} \text { (minimum) } \\ 538 & 43 \cdot 2 & 4 \cdot 72 \\ 411 & 30 \cdot 6 & 4 \cdot 85 \\ 256 & 34.2 & 4 \cdot 70\end{array}$

The equations relating titratable acidity (T.A.) and ammonia nitrogen during their rise and decline were found to be linear and highly significant (Table 2 ).

Table 2

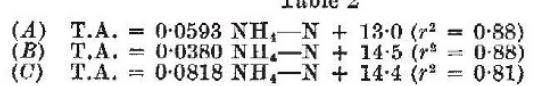

The equations are of the form $y=a x+b$. Thoro is evidence that the $b$ values refer to monobasic amino. reids and that the relationship $y=a x$ involves a separate process during which the increaso in titratable acidity is associated with the production of acids of higher dissociation (than the monobasic amino-acids) and which gradually disappoar with declining titratable acidity.

From equations (1)-(3) the proportions of ammonia to titratablo acidity expressed as equivalents and ignoring the $b$ factor are $1.20,1.88$ and 0.87 respectively, during the period of build-up and docline, that is, either ammonia or titratable acids are produced in excess of each other. The high value 1.88 must bo related to the application of ammonium sulphate. This alters the conclusion reached earlier ${ }^{1}$ on tho basis of equation (1) only and suggests that in the build-up of ammonia and acidity the compounds sould be drrived from separate sources. This may well bo so since the uptako of nitrate to some extent paralleled that of ammonia especially with the regrowth material.
It is possiblo, thon, that with Selaria ammonia accumulates as a neutral salt together with dicarboxylic acids derived from carboxylic motabolism. Accumulation could be due to a blook euused by low concentration of the enzymes responsible for amino-acid and amide formation. At a certain stage of growth, roughly the same in all instances and just prior to eulm elongation, this block is apparently overcome with a decline in both ammonia and titratable acidity presumably through amino-acid and amide synthosis leading eventually to protein formation. Amino-acid determinations on othanol extracts are being carried out and preliminary results reveal the presence of considerably more glycine and asparagine in the Brachiaria extracts than in thoso of Seturia. The significance of this abservation and the formulation of a more precise hypothesis than that outlined here should emerge whon moro amino-acid data are available.

Whatever the mechanism involvod, the repetitive pattern of behaviour with Setaria is interesting and one which, so far as we are aware, has not previously been reported for a grass growing undor natural conditions. A third sowing will be carried out in 1963 to test further tho occurronce of this particular pattern.

W' thank Mr. H. Hodgson of the Department of Agrieulture, Kenya, who is carrying out the amino-acid detorminations.

Makerere University College,

H. F. BIRCH

Kampala, Uganda.

Grassland Research Station, Kitale, Kenya.

${ }^{1}$ Birch, H. F., Hood, C. C., and Dougall, H. W., Nature, 194, 1195 (198z').

\section{MICROBIOLOGY}

\section{Characterization of Pools of Protein in Cells of Shigella flexneri F6S infected with Phage H-Sh}

THE lesions elicited by phage $H-S h$ in the susceptible cells of Shigella flexneri F6S have been examined by means of the fluorescence microscope, on smears treatod with acridine orange $e^{1,2}$ or better with coriphosphine ${ }^{3}$. With both techniques the normal cells show one or more yollow-green nuclei (DNA) in a red cytoplasm (RNA). The aspect of the lesions due to $H$-Sh vary somewhat following the multiplicity of infection, especially in tho earlier stages of tho eyclo.

The following description applios to bacteria infected with a multiplicity of two or threo phages por coll. After 15 min, in most bacteria, DNA appears finely fragmented and evenly distributed in the whole cytoplasm, but there are also some cells with one or two round nuelei which appear more brightly fluoresoent and larger than those in the normal cells. This latter aspect will persist, in some cells, to the end of the cyclo. After 30 min, the general aspect is not very different from that after $15 \mathrm{~min}$, but the cells aro somewhat onlarged. After 45 min, finely fragmented DNA still persists in some cells, but most of thess show large irregular pools of DNA with RNA still visible between them.

All cells are markedly hypertrophicd (twice the size of normal cells). At that time, one or two (raroly more) round little black spots with well-defined edges do appear in some of the infected bacteria. In cells stained by toluidine blue, or by the Robinow or the Gram methods, these spots, which may be considered as vacuoles, appear colour. less (Fig. 1). After $60 \mathrm{~min}$ tho cells aro larger than after 45 min (three times the size of normal cells) and more cells show largo pools of DNA, while RNA is in regression. The vacuolized cells are more numorous and the vacuoles larger than those previously observed. DNA appears frequently condonsed around the vacuoles. Some cells. 